\title{
Climate Evolution in Central Asia during the Past Few Million Years: A Case Study from Issyk Kul
}

\author{
by Hedi Oberhänsli and Peter Molnar
}

doi:10.2204/iodp.sd.13.09.2011

\section{Introduction}

The lake Issyk Kul occupies a deep basin within the Earth's most active intracontinental mountain belt, the Tien Shan, far from any oceanic influence. It offers a record of continental climate spanning millions of years that is likely unmatched by any other source.

A three-day workshop, with the same title as this report and sponsored by the International Continental Drilling Project and German Science Foundation, was held on 12-17 June 2011 on the shore of Issyk Kul to discuss the scientific justification for and the logistical aspects of scientific drilling of the lake. A two-day geological field trip followed the workshop. Forty-five scientists from twelve countries discussed three obvious targets for paleoclimatic study, a related study of erosion, and a study of how microbial life has evolved within the basin. The conclusion was that these research topics justify further consideration of deep continental drilling at Issyk Kul.

The premise underlying the paleoclimate questions is that climates within continents need not follow that recorded by, and studied well with, marine sediment. A particularly clear example is that glaciation within alpine settings is not

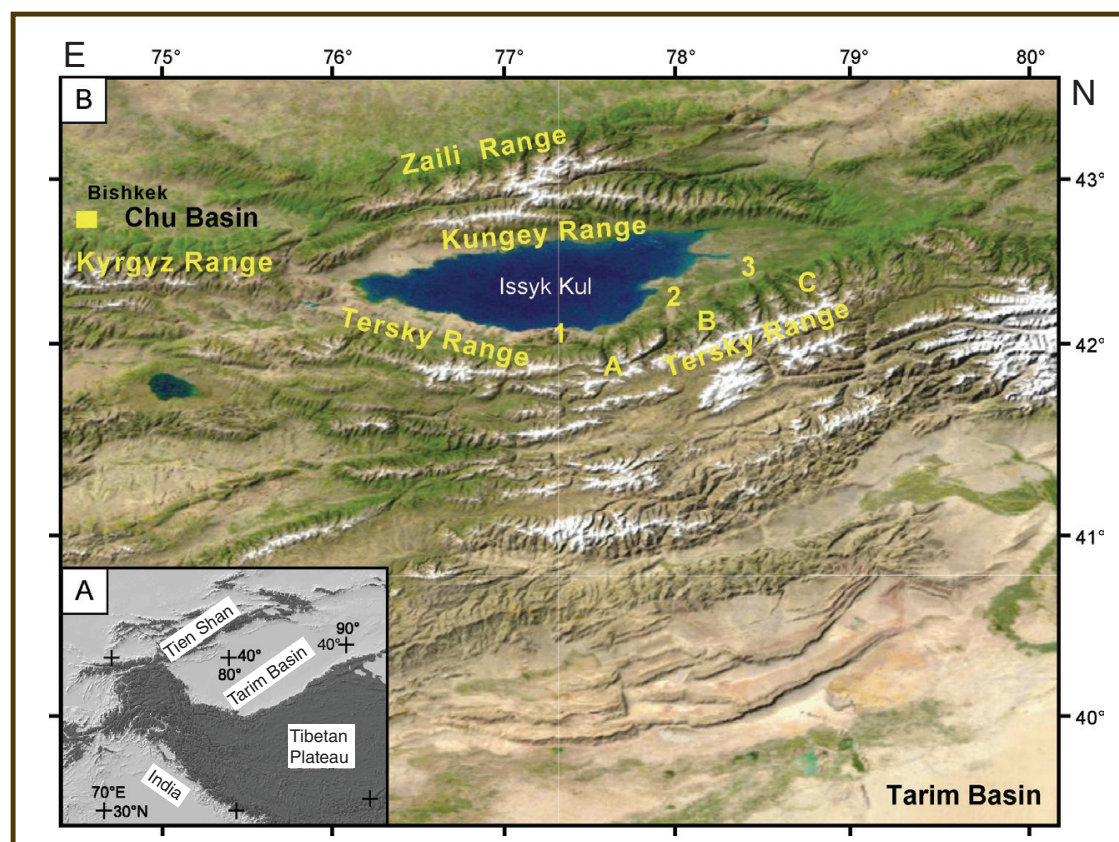

Figure 1. Topographic map of the Tien Shan showing the location of Issyk Kul and range-and-basin nature of the belt. synchronized with that of continental ice sheets; maximum advances of alpine glaciers in many regions precede the last glacial maximum (LGM) at $\sim 20 \mathrm{kyr}$ BP.

The major outcome of the meeting was the identification of two drilling targets: one within the lake that would reach as deep into Quaternary time as possible and certainly as far as $100 \mathrm{kyr} \mathrm{BP}$, and a second on shore that could penetrate sediment as old as 6-10 Ma.

\section{Geologic Background}

Issyk Kul (literally "hot lake" in Kyrgyz) occupies a deep topographic depression within the Tien Shan (Fig. 1). Observatories using GPS measurements (Fig. 2), modern seismicity, and active faulting indicate relatively rapid deformation and suggest that the Tien Shan is Earth's most active intracontinental mountain belt.

Seismicity in the Tien Shan is high, with four earthquakes since 1889 assigned magnitudes as large as 8 (Abdrakhmatov et al., 2002; Kondorskaya and Shebalin, 1977). Fault plane solutions of earthquakes consistently show reverse or thrust faulting. Evidence of active faulting is widespread (Abdrakhmatov et al., 2007; Chedia, 1986; Laverov and Makarov, 2005), and rates of slip on several faults exceed $1 \mathrm{~mm} \mathrm{yr}^{-1}$ (Chen et al., 2007; Thompson et al., 2002).

At present the Tarim Basin, which lies to the south of the Tien Shan, moves northward at $20 \pm 2 \mathrm{~mm} \mathrm{yr}^{-1}$ with respect to the Eurasian Plate to the north (Reigber et al., 2001; Zubovich et al., 2010). Deformation is not localized on the margins of the belt, but occurs throughout it, consistent with seismicity and studies of active faulting (Fig. 2). The present-day convergence rate between the Terskey Alatau south of Issyk Kul and the Kungey Alatau to its north is $\sim 5 \mathrm{~mm} \mathrm{yr}^{-1}$.

Mineral cooling ages (Bullen et al., 2003) suggest accelerated exhumation of parts of the Tien Shan since $\sim 10 \mathrm{Ma}$, and magnetostratigraphic dating of sediment in adjacent basins (Abdrakhmatov et al., 2001; Charreau et al., 2009; Ji et al., 2008; 
Sun and Zhang, 2009) suggest accelerated deposition of sediment since that time. Both findings are consistent with enhanced erosion due to growing relief beginning near or shortly before $10 \mathrm{Ma}$. How deformation has developed since that time, either as an average across the belt or in individual mountain ranges within the Tien Shan, remains poorly constrained.

The Cenozoic stratigraphy of Kyrgyzstan is commonly divided into four units that overlie a surface that had little relief prior to deposition onto it (Abdrakhmatov et al., 2001; Burgette, 2008). At the bottom is the Kokturpak group, commonly tens of meters thick, fine-grained, deeply weathered, and typically dark red in color, perhaps deposited from Cretaceous to Eocene and possibly as young as Miocene. Disconformably overlying it is the Shamsi Group with thickness varying from hundreds of meters to $\sim 2000 \mathrm{~m}$. It is relatively well-sorted, reddish sediment, rich in quartz and feldspar with abundant conglomerate. Magnetostratigraphy suggests that deposition began 12-13 Ma ago. The Chu Group overlies the Shamsi group, with assigned dates ranging from $8 \mathrm{Ma}$ to $4 \mathrm{Ma}$; in the Issyk Kul area, reported thicknesses range up to $\sim 2800 \mathrm{~m}$. It includes tabular beds with sandstone and conglomerate lenses interpreted as river channels of moderate size as well as lacustrine sediment and evaporites. Overlying the $\mathrm{Chu}$ group in many regions is coarse conglomerate of the Sharpyldak Formation. Thicknesses vary from tens to hundreds of meters to more than $1000 \mathrm{~m}$ in places. At the east end of the Issyk Kul basin, however, lacustrine sediment of Quaternary age is exposed.

At present, Issyk Kul sediment consists of a mixture of riverine sediment and endogenic carbonates (De Batist et al., 2001; Giralt et al., 2002). The steep northern and southern margins present evidence of slope failure, and mass-flow

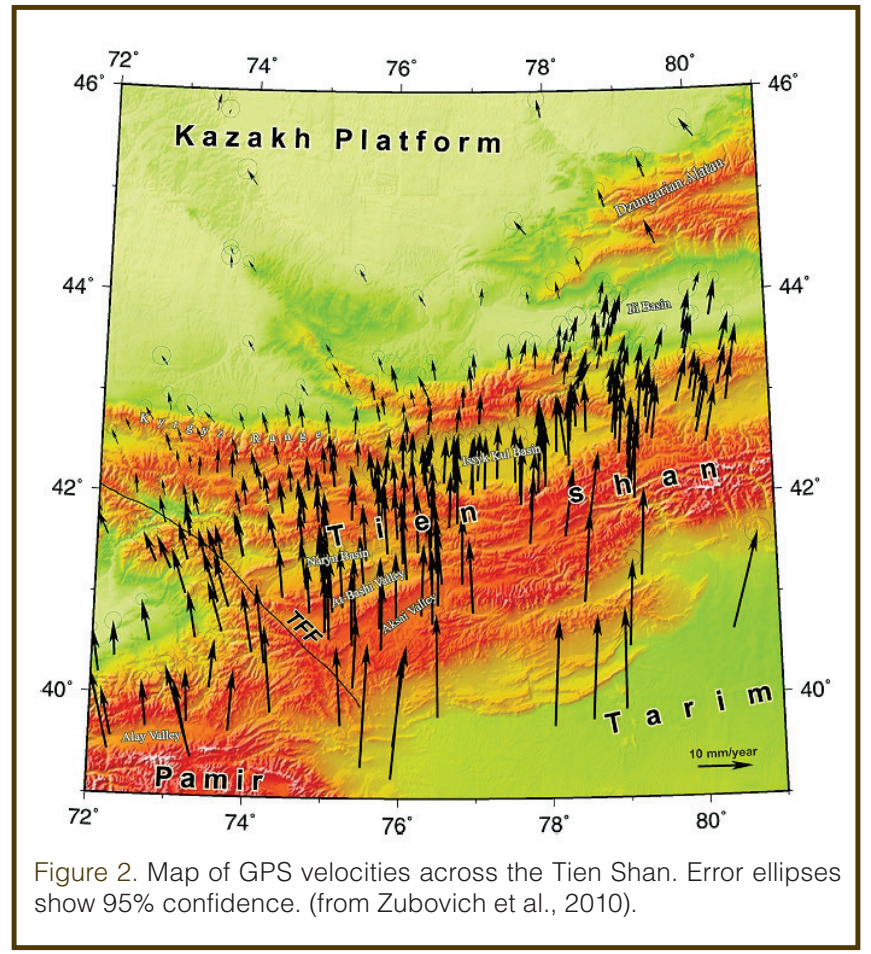

deposits are found at the foot of these steep slopes. Near the steep borders, only centimeter-thick fining-upwards sequences of small gravel and sand are present, whereas the central deep basin is filled with a mixture of carbonate hemipelagic sediment and fine terrigenous sediment that includes distal turbidite facies. The southern part of this deep central basin contains a topographic high, and available high-resolution seismic data and short gravity cores indicate that sedimentation there is dominated by bottom currents migrating up-slope towards the crest of the high. By contrast, deltaic sedimentation processes have dominated deposition on the eastern and western margins. Near the eastern and western shores, proximal deltaic sediment is found, whereas distal deltaic sediment (laminated silty-clay sediment) has been deposited closer to the central deep plain. Slope failure deposits dominate the fronts of both deltas.

\section{Modern Climate}

Issyk Kul and the Tien Shan lie within the mid-latitudes, far from the tropics where monsoons dominate climate, and where precipitation interacts profoundly with atmospheric circulation. At the same time, the Tien Shan is far from high-latitude conditions where extremes in the seasonal cycle play a crucial role, and where warming over the past century and a half has been most pronounced. Considerably more attention has been given to the Arctic than the mid-latitudes, and many view the study of mid-latitude climate as a gap in our understanding of climate dynamics.

The mid-latitudes, and the Issyk Kul region in particular, offer often under-appreciated features for climate study. For instance, changes in vegetation, either with continued global warming or on paleoclimate time scales, are much larger than in the tropics or high latitudes. Changes from forests to grassland, or vice versa, occur largely in mid-latitudes, and such changes affect both albedo and moisture availability. In the deep tropics, where changes in precipitation and the variability in temperature are small, large changes in vegetation are unlikely except in extreme climates. Similarly, at high latitudes, where trees are sparse, an expansion of woody vegetation is unlikely except in an extreme change in climate. Moreover, interannual variability of modern climate in and around the Tien Shan also is among the greatest on Earth (Aizen et al., 1997, 2001).

The Issyk Kul region offers some simple aspects that make its study attractive. For example, the most reliable part of General Circulation Models (GCMs) solves the Navier-Stokes equation to obtain the dynamics of flow, and although this solution depends on numerous parameterizations for local processes, such as latent and sensible heat transport from the surface, precipitation and latent heating of the remaining atmosphere, etc., many of these interactions can be described reliably. GCMs resolve well the physics of mid-latitude weather patterns and their associ- 
ated mechanisms of precipitation. Precipitation in mid-latitudes results from advection of moisture by the large-scale flow and by the subsequent lifting of moisture in mid-latitude cyclones and by the flow incident on large topographical obstacles, all of which are governed by processes that are explicitly and well represented in climate models.

The Issyk Kul sedimentary archive represents a potential source of record from an intracontinental region whose climate neither responds directly to monsoons nor is forced by adjacent marine conditions, making it an attractive target for isolating mid-latitude atmospheric circulation components of past climate

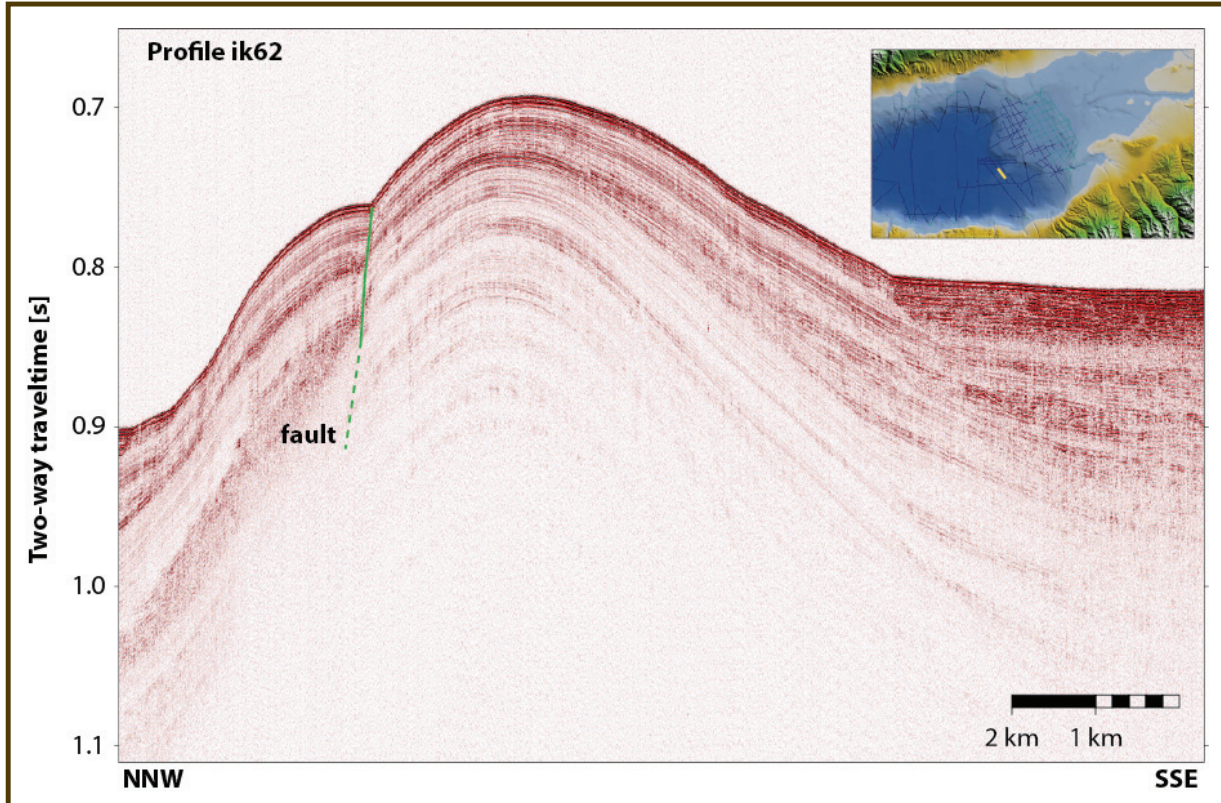

Figure 3. Seismic section that shows a subtle rise in bottom topography and with undisturbed sediment. (De Batist, M., unpublished; compiled by C. Gebhardt) changes on a range of timescales.

The climate of the Issyk Kul region is relatively simple but highly sensitive to vari-ations in the moisture supply, which affect both lake levels and the extent of Tien Shan alpine glaciation. It is possible to recover a long continuous sediment record from the Issyk Kul basin to test series of hypotheses at the junction of geomorphology, tectonics, paleoclimate, and biotic evolution.

\section{Scientific Questions That Merit Drilling of the Issyk Kul Basin}

We first discuss five questions that motivate scientific drilling of the Issyk Kul Basin: three bear directly on climate, a fourth concerns the role that climate change plays in erosion of high terrain, and a fifth tackles microbiological properties in an old, possibly endemic lake, which, due to changes in its water chemistry, promoted halotolerant organisms and eventually endemism. These questions overlap to varying degrees, as each in part concerns differences between climates of high central Asia and global climate. We then pose other additional questions that deep drillholes will help resolve and thus will broaden the scope of a major scientific drilling effort at Issyk Kul.

Hypothesis 1 . A semi-arid, continental climate characterizes the Issyk Kul watershed deep within a continental interior and far from large marine sources of water vapor. Today, its main moisture sources are the Mediterranean and the North Atlantic, with moisture arriving mostly during the spring. Issyk Kul is ideally suited to examine differing responses to advection of moisture from these sources and to direct temporal variations in insolation on an otherwise nearly pure continental climate.
Hypothesis 2. Seismic data (Fig. 3) from Issyk Kul reveal a bathymetric high that holds a stratigraphically continuous section, 150-200 m thick, of fine and at least partly laminated sediment. Based on prior stratigraphic studies in the basin (Giralt et al., 2002; Ricketts et al., 2001), it is likely that this sediment is calcareous and proxy-rich, with a sedimentation rate that will enable a high-resolution (roughly decadal to centennial) climate reconstruction back perhaps to 300-400 kyr BP. Turbidites, mass flow, and slumps seem not to have disturbed this section (Fig. 4). Millenial-scale abrupt climate climate changes, like Dansgaard-Oeschger (D-O) stadials whose origin seems to be in the North Atlantic, have been recoded well by speleothems in China, but recent work suggests that the connection is through the South Asian Monsoon (Pausata et al., 2011). The Issyk Kul region offers an ideal, intracontinental region to examine the direct response to such changes in the North Atlantic, without the strong modulation by the South Asian Monsoon.

Hypothesis 3. As noted earlier, alpine glaciers and continental ice sheets seem to respond differently to orbital scale forcing (Abramowski et al., 2006; Gillespie and Molnar, 1995; Owen et al., 2005), including the Tien Shan (Koppes et al., 2008; Xu et al., 2010), but such evidence, both global and specific to the Tien Shan, spans only the last glacial period, since $100 \mathrm{kyr}$ BP. In particular, due to the present-day aridity of the Issyk Kul region, glacial mass balance is most sensitive to amount of precipitation. A high-resolution, accurately dated history of glacial sediment input into the Issyk Kul basin will allow a reconstruction of the glacial history of its surroundings in the Tien Shan for several glacial cycles and hence an examination of how Alpine glaciers and continental ice sheets advance asynchronously over many cycles of orbital variability, if indeed they do. A detailed study of such asynchroneity could allow insights into how orbital 
variations affect not just ice sheets but continental climate in general.

Hypothesis 4. The geomorphological, tectonic, and paleoclimate communities differ, both among each other and within each group, on the relative roles played by tectonics (whether active or dead) and climate (and climate change) in affecting erosion rates (Molnar and England, 1990; Willenbring and von Blanckenburg, 2010; Zhang et al., 2001). Tectonic movement is needed for terrain to lie above sea level, but present-day elevations need not be results of active tectonics. Erosive processes differ in different climates, and changing climates (especially in the statistics of precipitation variability) might alter erosion rates so that current landscapes are not in equilibrium with the present-day climate. Testing the relative importance of climate and tectonics as they manifest themselves in erosion requires finding a region where changes in both climate and tectonics can be dated well. Issyk Kul might provide an excellent archive not only to date changes in erosion rates, but also to evaluate the roles of tectonics and climate change in affecting such erosion rates.

Hypothesis 5. A variety kinds of evidence, such as the periodic alternation of endogenic $\mathrm{Ca}$ - and $\mathrm{Mg}$-bearing carbonates and changes in the concentration of noble gases in sediment pore water (Brennwald et al., 2004), suggests that the Issyk Kul has alternated between being fresh and saline at many times in the past. Moreover, seismic surveys clearly show evidence of several dramatic lowstands of Issyk $\mathrm{Kul}$, and historic records indicate repeated episodes of outflow from what is today a closed-basin lake. As various organisms thrive better in fresh than saline water, and vice versa, salinity changes may have profoundly affected taxonomic diversity in the basin and the development of endemism. At present, Issyk Kul is species-poor compared to most freshwater lakes and the oceans. Thus, Issyk Kul offers a field laboratory for studying how organisms respond to larger temporal variations in salinity, and perhaps evolve in response to such changes.

\section{Other Questions Potentially Solved with Cores from the Issyk Kul Basin}

The tectonics community at the workshop posed a number of questions that do not by themselves merit the high cost of drilling, but whose questions might be answered, or partly answered, with results from cores taken from the Issyk Kul basin. Moreover, some questions bear on local geology and local hazards, and all participants agreed that if a drilling program pokes holes into Kyrgyz territory, the Kyrgyz people ought to reap benefits from such a program.

Dating of sedimentary rock. As noted above, the Cenozoic stratigraphy of Kyrgyzstan is commonly divided into four units. Resolving when and how the Issyk Kul basin formed
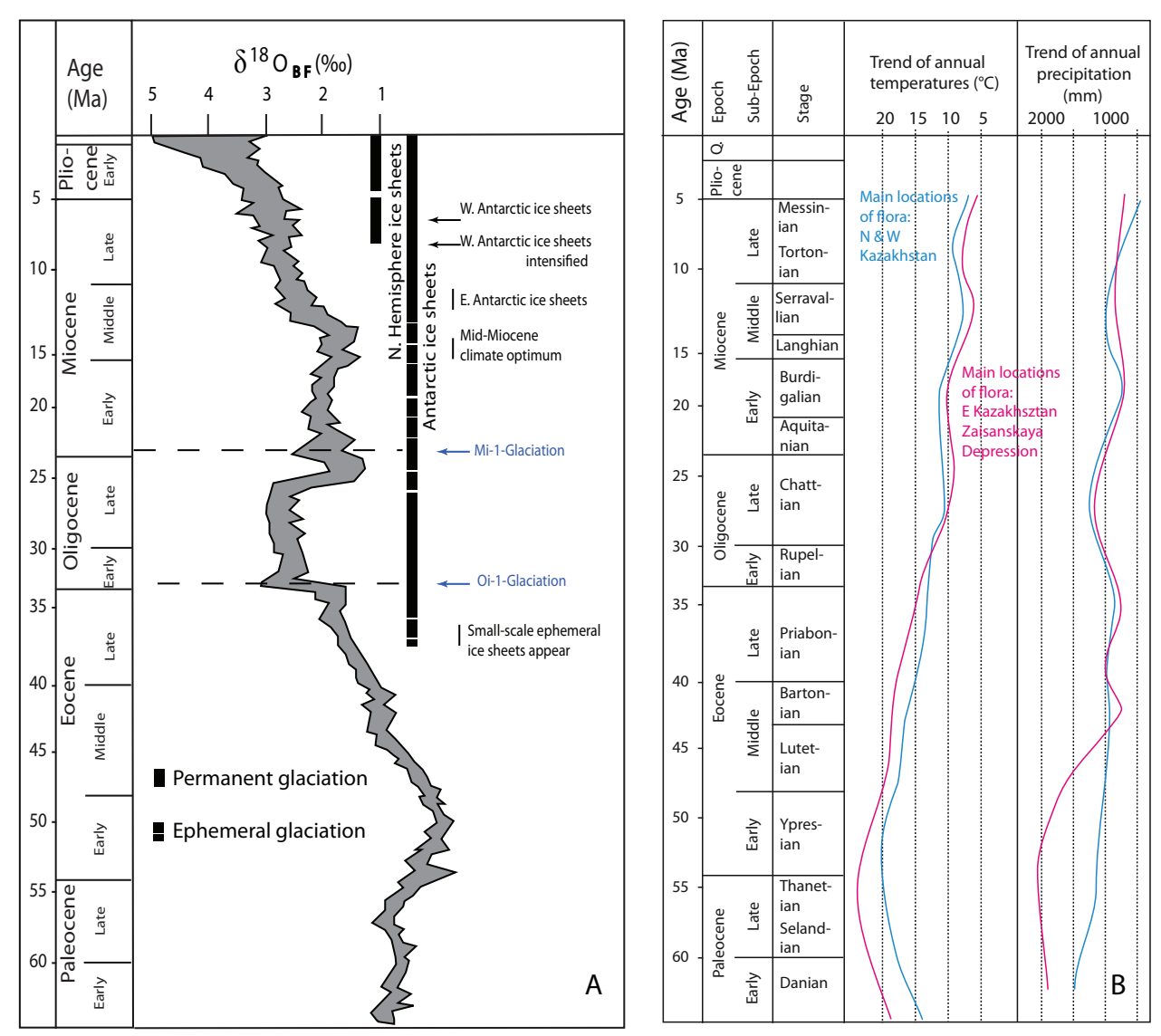

Figure 4. [A] The marine $\delta^{18} \mathrm{O}$ synthesis of Zachos et al. [2001] compared with [B] the Central Asian climate history from Akhmetyev et al. (2005). and when sedimentary facies changed is important for interpreting the contemporaneous climatic record archived within the basin.

Seismites and paleoearthquakes. The Kyrgyz people live with a serious threat of earthquake disaster. For instance, in the northern Tien Shan of Kyrgyzstan and Kazakhstan, several major earthquakes occurred in historical times: in 1885 (Ms 6.9), 1887 (Ms 7.3), 1889 (Ms 8.3), and 1911 (Ms 8.1) (Abdrakhmatov et al., 2002). The latter two events are among the largest known intracontinental earthquakes worldwide, but the recurrence intervals of such earthquakes, which could be thousands to tens of thousands of years, are still unconstrained. If seismites can be found in lake sediment, they might provide a long record of earthquake 
activity far beyond instrumental records and recorded history. If found, seismites from the Issyk Kul basin could significantly enhance our knowledge of the earthquake history of the Tien Shan, as well as serving as a case study for other low-strain regions worldwide.

Accurate measurements of heat flux. The state of the lower crust-brittle or ductile, and in other respects, too-depends largely on the temperature (but also on the degree of hydration) at relevant depths. Accurate measurements of temperatures in deep holes could address two quite different problems: one relevant to geodynamics and the other to climate over the past several thousand to one hundred thousand years.

Changes in the locus and rate of deformation. Finally, a topic that was discussed at some length and that interested many participants concerns the following questions. (1) How have changes in the locus and rate of deformation over the past 5-10 Ma both enabled sediment production and generated sediment accommodation space in the Issyk Kul basin, which thereby conditioned the landscape for climate-induced change? (2) Can we find evidence that Issyk-Kul surface processes have played an active role in shaping tectonic deformation, rather than just passively responding to it (Garcia-Castellanos, 2007; Whipple, 2009)?

\section{Key Questions for Drill Site Selection}

Several questions motivated the workshop discussion. What drilling targets allow the climate and tectonic-related questions to be answered most effectively? What are the geometry, depth, and timing of basin formation? What is the sedimentary architecture? Where in the stratigraphy are regressions and transgressions located? Preliminary data allow partial answers to these questions, but further seismic profiling planned for 2012 should answer at least some of these questions.

Available background data include bathymetric surveys and a detailed seismic survey carried out in 1982 and earlier in Soviet times. In addition, three seismic surveys were carried out in 1997, 2001, and 2002, using digital recording, with accompanying retrieval of several short cores (Giralt et al., 2002; Ricketts et al., 2001). In addition, 100 (or more) wells of up to $5-\mathrm{km}$ depth have been drilled on land (Duchkov et al., 2001). Most of these cores are at least in part accessible. In addition to geologic maps made in Soviet times, a new atlas to be published soon and geologic maps of selected portions of the north slope of the range south of the lake (Burgette, 2008) are available. Furthermore, elevation data with 70-m horizontal resolution are digitally available for the region.

Given these data, the following additional scientific investigations have been deemed necessary.
- In selected areas, further bathymetric surveys are needed, particularly around the possible drill sites to acquire accurate water depths and bottom topographies. These surveys would help to delineate features of interest in the deepest basin.

- In regions with depths shallower than $120 \mathrm{~m}$, which is the minimum drop in lake level during lowstands and where river incision may have removed sediment, denser seismic coverage than currently exists is needed.

- Seismic data from selected deeper parts and/or land is needed to extend existing coverage.

- Seismic refraction is necessary to determine seismic velocities and to define the geometry where layers are not flat in intervals between reflectors.

- A map of recent lake sediment based on cores that have been examined would be helpful.

- Finally, much data exists from drilling around the lake. Acquiring those data, digitizing them, and correlating them with seismic and outcrop data would help decide where a hole would be most likely to yield good results. A plan is underway to digitize logs from some such wells.

These pre-site surveys will help to define specific drilling locations and depths, as well as informing some the following questions.

- How deep is the basin and/or the bedrock?

- What are the geometry of the basin floor and timing of its formation?

- To what extent is the basin the result of recent or ancient tectonics?

- What is the nature of the infill; how much is terrestrial and how much lacustrine? What has been its stratigraphic development?

- Where has sediment that was transported by rivers been deposited? How much has been deposited by plumes and as turbidites?

- To what extent is the bathymetry the result of progradation from the east and the west? How have regressions, with possible lowering of the level down to $300 \mathrm{~m}$, affected the bathymetry and sediment distribution?

- How large and when in the past were lake level fluctuations? Did any major incision/erosion remove sediment? Have there been catastrophic floods? Why are there high lake terraces? What are the ages and distribution of these lake high-stand terraces?

\section{Possible Drill Sites}

Four possibilities were discussed. They are listed below not in any order but along with the most important pros and cons. 
Site A: In the deep abyssal plain. If the Drilling, Observation and Sampling of the Earth's Continental Crust (DOSSEC) rig were used, then with a water depth of $650 \mathrm{~m}$, a penetration of a $850-\mathrm{m}$ deep well, and a sedimentation rate of $0.3 \mathrm{~mm} \mathrm{yr}^{-1}$ in this region, it could reach sediment with a maximum age of $2.8 \mathrm{Ma}$.

Virtues: Such a core could provide a complete record of undisturbed sediment since continental ice sheets first developed in North America.

Weaknesses: Such drilling will challenge existing drilling techniques, as the season for drilling is short. The dynamic positioning system would likely be required for the drilling platform to hold position. This would increase costs dramatically. Moreover, the core might contain thick layers of sand, deposited as turbidites, which would be hard to penetrate.

Site B: A well at a water depth of $300 \mathrm{~m}$. Again, if sediment had been deposited at (only) $0.2 \mathrm{~mm} \mathrm{yr}^{-1}$ (Vermeesch et al., 2004), a penetration of $1200 \mathrm{~m}$, as with a DOSSEC rig, would reach a sediment with a maximum age of $6 \mathrm{Ma}$.

Virtues: Such a core might contain a long, complete but perhaps condensed record.

Weaknesses: Again, a short drilling season would challenge existing drilling techniques, and again anchoring of the drill rig would be required. Also again, there is the risk of drilling sand. Furthermore, the sedimentation rate might be much higher.

Site C: A well drilled on land on the plain just east of the lake. Penetration to $1500 \mathrm{~m}$ depth with sedimentation at a high average rate of $1 \mathrm{~mm} \mathrm{yr}^{-1}$ would reach a maximum of $1.5 \mathrm{Ma}$, but at $0.2 \mathrm{~mm} \mathrm{yr}^{-1}$, it would reach $7.5 \mathrm{Ma}$. Such a well could penetrate farther, if a commercial rig rather than the DOSSEC rig were to be used.

Virtues: Logistics should be relatively easy, and costs should be relatively low. Other nearby wells drilled in Soviet times demonstrate feasibility. Moreover, downhole logging should be easier than on the lake.

Weaknesses: Potentially large stratigraphic gaps might exist, and sediment might be coarse. Before such an undertaking, seismic reflection profiling on land is needed.

Site D: A well sited on an anticline at $500 \mathrm{~m}$ water depth at the eastern end of the deep central basin. Assuming a DOSSEC rig is used, a penetration of $1000 \mathrm{~m}$ into sediment deposited at $0.3 \mathrm{~mm} \mathrm{yr}^{-1}$ would reach a maximum age of 3.3 my.

Virtues: A long, complete but perhaps slightly condensed record would be obtained. The likelihood of drilling through coarse-grained material/turbidites is lowest among the sites considered.

Weaknesses: Again, a short drilling season would challenge existing drilling techniques, and again dynamic positioning system would likely be required for the drilling platform to hold position. This would increase costs dramatically. In addition, from the existing seismic profiling, a well might intersect a fault at depth.
The workshop participants did not discuss at length the virtues and weaknesses of all sites in detail, but the general consensus was that the best option for reaching sediment several million years old was Site C, and the best for paleoclimatic studies on the $100-\mathrm{ky}$ timescales was Site D.

\section{References}

Abrakhmatov, K.E., Djanuzakov, K.E., and Delvaux, D., 2002. Active tectonics and seismic hazard of the Issyk-Kul basin in the Kyrgyz Tian-Shan, In Klerkx, J., and Imanackunov, B. (Eds.) Lake Issyk-Kul: Its Natural Environment: Dordrecht (NATO Science Series, Kluwer), 147-160.

Abdrakhmatov, K.E., Thompson, S., and Weldon, R., 2007. Active Tectonics of the Tien Shan: Bishkek, Kyrgyzstan (Ilim), in Russian.

Abdrakhmatov, K.E., Weldon, R., Thompson, S., Burbank, D., Rubin, Ch., Miller, M., and Molnar, P., 2001. Origin, direction, and rate of modern compression in the central Tien Shan, Kyrgyzstan. Geologiya i Geofizika (Russian Geology \& Geophysics), 42:1585-1609.

Abramowski, U., Bergau, A., Seebach, D., Zech, R., Glaser, B., Sosin, P., Kubik, P.W., and Zech, W., 2006. Pleistocene glaciations of Central Asia: Results from ${ }^{10} \mathrm{Be}$ surface exposure ages of erratic boulders from the Pamir (Tajikistan), and the Alay-Turkestan range (Kyrgyzstan). Quat. Sci. Rev., 25:1080-1096. doi:10.1016/j.quascirev.2005.10.003

Aizen, E.M., Aizen, V.B., Melack, J.M., Nakamura, T., and Ohta, T., 2001. Precipitation and atmospheric circulation patterns at mid-latitudes of Asia. Int. J. Climatology, 21:535-556. doi:10.1002/joc. 626

Aizen, V.B., Aizen, E.M., Melack, J., and Dozier, J., 1997. Climatic and hydrologic changes in the Tien Shan, Central Asia. J. Climate, 10:1393-1404. doi:10.1175/1520-0442(1997)010< 1393:CAHCIT>2.0.CO;2

Akhmetyev, M.A., Dodoniv, A.E., Somikova, M.V., Spasskaya, I.I., Kremenetsky, K.V., and Klimanov, V.A., 2005. Kazakhstan and Central Asia (plains and foothills). In Velichko, A.A., and Nechaev, V.P. (Eds.), Cenozoic Climatic and Environmental Changes in Russia, Geol. Soc. Am. Special Paper, 382:139-161.

Brennwald, M.S., Peeters, F., Imboden, D.M., Giralt, S., Hofer, M., Livingstone, D.M., Klump, S., Strassmann, K., and Kipfer, R., 2004. Atmospheric noble gases in lake sediment pore water as proxies for environmental change. Geophys. Res. Lett., 31:L04202. doi:10.1029/2003GL019153

Bullen, M.E., Burbank, D.W., and Garver, J.I., 2003. Building the northern Tien Shan: Integrated thermal, structural, and topographic constraints. J. Geol., 111:149-165. doi:10.1086/ 345840

Burgette, R.J., 2008. Uplift in response to tectonic convergence: The Kyrgyz Tien Shan and Cascadia subduction zone [Ph.D. dissert.]. University of Oregon, Eugene, OR.

Charreau, J., Chen, Y., Gilder, S., Barrier, L., Dominguez, S., Augier, R., Sen, S., et al., 2009. Neogene uplift of the Tian Shan Mountains observed in the magnetic record of the Jingou River section (northwest China). Tectonics, 28:TC2008. doi:10.1029/2007TC002137

Chedia, O.K., 1986. Morphostructures and Neotectonism of the Tien Shan: Frunze (Ilim), in Russian. 
Chen, J., Heermance, R., Burbank, D.W., Scharer, K.M., Miao, J., and Wang, C., 2007. Quantification of growth and lateral propagation of the Kashi anticline, southwest Chinese Tian Shan. J. Geophys. Res., 112:B03S16. doi:10.1029/2006JB004345

De Batist, M., Imbo, Y., Vermeesch, P., Klerkx, J., Giralt, S., Delvaux, D., Lignier, V., Beck, C., Kalugin, I., and Abdrakhmatov, K.E., 2001. Bathymetry and sedimentary environments of Lake Issyk-Kul, Kyrgyz Republic (Central Asia): A large, high-altitude, tectonic lake. In Klerkx, J., and Imanackunov, B. (Eds.), Lake Issyk-Kul: Its Natural Environment: Dordrecht (NATO Science Series, Kluwer), 101-123.

Duchkov, A.D., Shvartsman, Yu.G., and Sokolova, L.S., 2001. Deep heat flow in the Tien Shan: Advances and drawbacks. Geologiya $i$ Geofizika (Russian Geology \& Geophysics), 42:1436-1452.

Garcia-Castellanos, D., 2007. The role of climate during high plateau formation. Insights from numerical experiments. Earth Planet. Sci. Lett., 257:372-390. doi:10.1016/j.epsl.2007. 02.039

Gillespie, A., and Molnar, P., 1995. Asynchronous maximum advances of mountain and continental glaciers. Rev. Geophys., 33:311-364. doi:10.1029/95RG00995

Giralt, S., Klerkx, J., Riera, S., Julia, R., Lignier, V., Beck, C., De Batist, M., and Kalugin, I., 2002. Recent paleoenvironmental evolution of Lake Issyk-Kul. In Klerkx, J., and Imanackunov, B. (Eds.), Lake Issyk-Kul: Its Natural Environment: Dordrecht (NATO Science Series, Kluwer), 125-145.

Ji, J., Luo, P., White, P., Jiang, H., Gao, L., and Ding, Z., 2008. Episodic uplift of the Tianshan Mountains since the late Oligocene constrained by magnetostratigraphy of the Jingou River section, in the southern margin of the Junggar Basin, China. J. Geophys. Res., 113:B05102. doi:10.1029/2007JB005064

Kondorskaya, N.V., and Shebalin, N.V., 1977. New Catalog of Strong Earthquakes in the Territory of the USSR: Moscow (Nauka), in Russian.

Koppes, M., Gillespie, A.R., Burke, R.M., Thompson, S.C., and Stone, J., 2008. Late Quaternary glaciation in the Kyrgyz Tien Shan. Quat. Sci. Rev. 27:846-866.

Laverov, N.P., and Makarov, V.I., 2005. Recent Geodynamics of Intracontinental Areas of Collision Mountain Building (Central Asia): Moscow (Sci. World).

Molnar, P., and England, P., 1990. Late Cenozoic uplift of mountain ranges and global climate change: Chicken or egg? Nature, 346:29-34. doi:10.1038/346029a 0

Owen, L.A., Finkel, R.C., Barnard, P.L., Haizhou, M., Asahi, K., Caffee, M.W., and Derbyshire, E., 2005. Climatic and topographic controls on the style and timing of Late Quaternary glaciation throughout Tibet and the Himalaya defined by ${ }^{10} \mathrm{Be}$ cosmogenic radionuclide surface exposure dating. Quat. Sci. Rev., 24:1391-1411. doi:10.1016/j.quascirev. 2004.10.014

Pausata, F.S.R., Battisti, D.S., Nisancioglu, K.H., and Bitz, C.M., 2011. Chinese stalagmite $\delta^{18} \mathrm{O}$ controlled by changes in the Indian monsoon during a simulated Heinrich event. Nature Geoscience, 4:474-480.

Reigber, Ch., Michel, G.W., Galas, R., Angermann, D., Klotz, J., Chen, J.Y., Papschev, A., Arslanov, R., Tzurkov, V.E., and Ishanov, M.C., 2001. New space geodetic constraints on the distribution of deformation in Central Asia. Earth Planet. Sci. Lett.,
191:157-165. doi:10.1016/S0012-821X(01)00414-9

Ricketts, R.D., Johnson, T.C., Brown, E.T., Rasmussen, K.A., and Romanovsky, V.V., 2001. The Holocene paleolimnology of Lake Issyk-Kul, Kyrgyzstan: Trace element and stable isotope composition of ostracodes. Palaeogeogr. Palaeoclimatol. Palaeoecol., 176:207-227. doi:10.1016/ S0031-0182(01)00339-X

Sun, J., and Zhang, Z., 2009. Syntectonic growth strata and implications for late Cenozoic tectonic uplift in the northern Tian Shan, China. Tectonophysics, 463:60-68. doi:10.1016/j. tecto.2008.09.008

Thompson, S.C., Weldon, R.J., Rubin, C.M., Abdrakhmatov, K., Molnar, P., and Berger, G.W., 2002. Late Quaternary slip rates across the central Tien Shan, Kyrgyzstan, central Asia. J. Geophys. Res., 107(B9):2203. doi:10.1029/2001 JB000596

Vermeesch, P., Poort, J., Duchkov, A.D., Klerkx, J. and De Batist, M., 2004. Lake Issyk-Kul (Tien Shan): Unusually low heat flow in an active intermontane basin. Geologiya I Geofizika, 45(5): 616-625.

Whipple, K.X., 2009. The influence of climate on the tectonic evolution of mountain belts. Nature Geosci., 2:97-104. doi:10.1038/ ngeo413

Willenbring, J.K., and von Blanckenburg, F., 2010. Long-term stability of global erosion rates and weathering during late-Cenozoic cooling. Nature, 465:211-214. doi:10.1038/ nature09044

Xu, X., Kleidon, A., Miller, L., Wang, S., Wang, L., and Dong, G., 2010. Late Quaternary glaciation in the Tianshan and implications for palaeoclimatic change: A review. Boreas, 39:215-232. doi:10.1111/j.1502-3885.2009.00118.x

Zachos, J., Pagani, M., Sloan, L., Thomas, E., and Billups, K., 2001. Trends, thythms, and aberrations in global climate $65 \mathrm{Ma}$ to present. Science; Apr 27, 2001; 292, 551. doi:10.1126/ science. 1059412

Zhang, P., Molnar, P., and Downs, W.R., 2001. Increased sedimentation rates and grain sizes 2-4 Myr ago due to the influence of climate change on erosion rates. Nature, 410:891-897. doi: $10.1038 / 35073504$

Zubovich, A.V., Wang, X., Scherba, Y.G., Schelochkov, G.G., Reilinger, R., Reigber, C., Mosienko, O.I., et al., 2010. GPS velocity field for the Tien Shan and surrounding regions. Tectonics, 29:TC6014. doi:10.1029/2010TC002772

\section{Authors}

Hedi Oberhänsli, Museum of Natural History Berlin, Invalidenstrasse 43, 10115 Berlin, Germany, e-mail: hedi. oberhaensli@mfn-berlin.de.

Peter Molnar, Department of Geological Sciences and Cooperative Institute for Research in Environmental Sciences (CIRES), University of Colorado at Boulder, Boulder, CO 80309-0216, U.S.A., e-mail: molnar@colorado. edu. 